\title{
A Review of Landscape Design as a Means of Controlling Gully Erosion
}

\author{
Igwe, P.U.*; Chinedu, O.C.; Nlem E.U.; Nwezi, C.C.;Ezekwu, J.C.
}

Department of Environmental Management, Chukwuemeka Odumegwu Ojukwu University, P.M.B. 02, Uli, Anambra State, Nigeria

\begin{abstract}
Gully erosion is the most visible and devastating form of soil erosion known to be one of the leading causes of land degradation worldwide. Landscape design is one of the techniques used in combating this problem. The objective of this paper is to review the use of landscape design in controlling gully erosion. The method used is a review of academic articles, conference papers, internet materials, textbooks and publicly available materials on landscape design and gully erosion. The results of this study indicated that previous authors whose works were reviewed have a convergent view that the use of vegetative approach, an aspect to landscape design, must be practiced for effective control of gullies. On the other hand, however, previous authors have divergent views on the use of structural approach, another aspect to landscape design, for control of gully erosion. Recommendations of this study include: (1) planting of a combination of woody trees and grasses; (2) use of some locally accessible structures for example, sieve structures; and (3) practise of agroforestry.
\end{abstract}

Keywords - Landscape Design, Gully Erosion, Review, Sustainable Development, Structure, Vegetation.

\section{INTRODUCTION}

Gully erosion has been recognized as the major cause of land degradation worldwide (Musa, Ahmed, Muhammed and Abdul, 2016). According to them, it is fast becoming the most reoccurring disaster in many countries of the world. Gullies are steep sided watercourses, marked by stepped longitudinal profile and commonly an abrupt channel head, subject to intermittent flow of water (Khairulmaini and Fatemeh, 2011). Poesen (2011) observed that gullies are among the morphological indication of long periods of soil erosion revealing the effect of atmospheric adjustment such as heavy rainfall and land use practices in the landscape. Gully erosion has attracted a growing interest as reflected by two recent international conferences: one in Leuven, Belgium (Poesen and Valentin, 2003) and one in Chengdu, China (Valentin, Poesen and Li, 2005).
By removing vegetation cover, the erosion-resisting capacity of the soilbecomes disturbed (Rickson, 2001). He also opined that when the kinetic energy of rainfall splash increases, it results in increases in soilseparation. He further stated that hydraulic surface flow mostly increases with lack of vegetation cover, which inevitablyincreases soil susceptibility to erosion mostly gully, by reducing cohesion and shear strength. Ehiorobo and Audu(2012) reported that gully erosion occurs due to extreme overflow of fluid with a very high speed and energy to remove and transmit soil particles down-hill slope.In most instances, the development of gullies is caused byovergrazing, road construction and urbanization, log haulage, improper farming andirrigation practices (Valentin et al.,2005).

The need to understand how to monitor and prevent gulling is particularly acute (Poesen, Nachtergaele Verstraten and Valentin, 2003) and the search forinexpensive, durable, low maintenance techniques to control gully erosion has proven elusive (Norton, Bowannie, Peynetsa, Quandelacy and Siebert, 2002). It is important therefore, that a holistic understanding of gully erosion should involve collaborative inputs from experts in diverse fields like chemists, geologists, biologists and others (Brevik, Cerda, MataixSolera, Pereg, Quinton, Six and Van, 2015).

Landscape as an essential part of the environment which includes topography, vegetation and associated plants and soil, water bodies, is one of the most visual needs of people (Zheng, Zhang and Chen, 2011). Williams and Tilt (2006) opined that an effective landscape design can become an integral part of a good community environment. A well defined landscape space can enhance the quality of living areas which meets people's preferences (VanDerZanden and Rodie, 2008). A multifunctional landscape design solution must embrace the various ecosystem services that have already been bequeathed to a land area. These services include: (1) supporting and biophysical services (e.g., protecting and enhancing biodiversity and water quantity and quality); (2) provisioning services (e.g., production of energy and other utilitarian resources); (3) regulating 
services (e.g., waste reduction and reuse); and (4) cultural and social services (e.g., visual quality, beauty, human health, and recreational opportunity) (Lundy and Wade, 2011). Landscape design is thus defined as the art of modifying an area for aesthetic or practical reasons (David, 2017).

Amangabara(2012) stated that erosion control is an important factor in landscape design and the prevention of erosion must be top priority during the life cycle of planning for soil conservation in any landscape design. The application of landscape design for controlling gullies requires a good knowledge of hydrometeorology and surface hydrology (Professional Landscape Design, 2007).Controlling gully erosion is a multi-approach goal in that there are three main areas to review in any landscape design project involving conservation and they are design consideration, vegetation selection and soil treatments (Blair, 2014).This paper is thus focused on reviewing the use of landscape designs whether vegetation or artificial installations in controlling gully erosion.

\subsection{Statement of the Problem}

Gully erosion usually has unpredictable impacts that are often serious and flashy(Nyssen, Poesen, Moeyersons, Deckers, Miiku and Lang, 2004).They also asserted that in the Ethiopian highlands, the development ofgullies has led to an enlarged drainage of the inter gully areas, resulting in soil moisturedecrease and a corresponding crop yield reduction on plots located near the gully walls. In tropicalnorth-western Australia, about $80 \%$ of the sediment in the Lake Argyle reservoir hascome from gully and channel erosion and less than $10 \%$ from the catchment in the area of highly erodible soils formed on sedimentary rocks (Wasson,Caitcheon, Murray, McCullochand Quade, 2002). Gully erosion has also caused loss of farmland leading to drastic decrease in soil productivity, loss of property and threat to life resulting from food shortage and famine (Abdulfatai, Okunlola, Akande, Momohand Ibrahim, 2014).

According to Blair (2014), artificial installations used forerosion control in landscape design are effective to certain extents but may however besubject to decayand become less effective overtime. He was also of the opinion that some of these installations are limited in capacity and that it has been common practice to implant concrete or rock barriers intoerosion gullies in the hope that a solid barrier will counteract erosiveactivity and capture sediment.He further stated that these efforts to control gully erosionwith a solid barrier though helpful at the onset of installation usually fail.An example is the sieve structure which can only slow down gully water flows but not stop them (Layne, BreinDemisachew, Jaldesa, Badasa and Dereje, 2015). Hydrological knowledge needed for effective implementation of landscape designs is most times relegated to the background especially in developing countries, hence, the problem of gully erosion and its negative impacts continue(Amangabara, 2012).

\subsection{Objective}

The objective of this study is to review the use of landscape design in controlling gully erosion.

\section{CONCEPTUAL FRAMEWORK: SUSTAINABLE DEVELOPMENT}

This research is based on the concept of sustainable development. Morelli (2010) saw sustainable development as meeting the resources and services needs for current and future generations without compromising the health of the ecosystems that provide and more specifically as a condition of balance, residence and interconnection that allows human society to satisfy its needs while neither exceeding the capacity of its ecosystems to continue to regenerate the services necessary to meet those needs nor by our actions diminishing biological diversity.World Conference on Environment and Development (WCED) (1987) opined that sustainable development is development that meets the needs of the present without compromising the ability of future generations to meet their own needs. This research sets to review landscape design as a means for gully erosion control so as to build in sustainability into the management of the phenomenon.

\section{METHOD}

The researchers gathered a total of 34 materials for this research, but were able to summarize the characteristics of 10 that were deemed more relevant tolandscape design as means of controlling gully erosion and sustainable development. This research made use of academic articles, conference papers, internet materials, textbooks and publicly available materials on landscape design and gully erosion.

\section{LITERATURE REVIEW}

Markus, Miloš, Jozef, Štefan and Pavol(2013) stated that erosion as one of the major and most widespread forms of land degradation, poses severe limitations to sustainable agricultural land use, reduces on-farm soil productivity and contributes to water-quality problems from the 
accumulation of sediments and agro-chemicals in waterways. They also claimed that gullies are formed mostly after deforestation,the beginnings of agricultural utilization and that they are often controlledby access roads or by other linear artificial landscape elements. They reported further that accelerated water erosion in general includinggulling was most effective when human interference wascombined with colder and wetter climatic fluctuations.

Prolonged erosion causes irreversible soil loss over time, reducing the ecological functions of soil: mainly biomass production, crop yields due to removal of nutrients for plant growth, and reduction in soil-filtering capacity due to disturbance of the hydrological cycle; from precipitation to runoff (Víctor, Dur'an, Carmen and Rodr'iguez ,2008). They further stated that runoff is a fundamental process in land degradation, causing soil erosion and influencing the soil water balance and hydrology of the catchments. They also noted that in a wide range of environments, both runoff and sediment loss will decrease exponentially as the percentage of vegetation cover increases and that soilerosion resistance increases exponentially with greater root density.

McGarigal (2006) defined landscape as an area that isspatially heterogeneous in at least one factor of interest. He pointed out that the concept of landscape differs from thetraditional ecosystem concept in focusing on groups of ecosystems and the interactions amongthem and that the focus is on spatial heterogeneity and its impact on process.According to Williams and Tilt (2006), landscape design is the art of developing property for its greatest use and enjoyment and canbecome an integral part of a good community environment.They reported that increasing evidence has shown that designcan achieve multifunctional benefits if the rolethat natureplays is taken into consideration. They further opined that landscape design has multiple benefits such as decentralized and naturalized ways of managing stormwater, runoff deduction and water quality enhancement. Musacchio (2009) was of the opinion that there is the need to be an intricate balance between the environmental and socio-economic aspects of a design to achieve sustainability goals. He further claimed that every design has its main focus and project success should be measured based on its main project goal, rather than by a rigid set of metrics.

Katherine, Valerie, Carissa and Eric (2002) stated that understanding gully erosion mechanism is very important to design the gully erosion measurement system and develop its control. They observed that the use of vegetation to control erosion has been practised in many countries for centuries. They enumerated some factors to consider when using vegetation to control erosion which include texture and layering of materials, existing vegetation and surface and groundwater movement from upslope and so on. In the view of Yifan, Yongqiu and Wen (2011), the control of gully erosion can be divided into three approaches. They stated that the firstis to try to stabilize the gully using the vegetation cover method, the second is to control the runoff flow from upstream of the gully and the third is to build some soil conservation works inside the gully to restore the hydraulic balance of the gully. There are two essential components to managing the erosion problem: rehabilitating the landscape to control the source of soil loss, and reducing sediment flow through the gully system (Layne, Brien, Demisachew, Jaldesa, Bedasa, and Dereje, 2015). They argued that gully erosion cannot be stopped completely, especially when gullies receive rushing floods of water from heavy rainfall but that gullies can be treated to achieve longterm suppression of sediment transport, and when combined with better landscape management the erosion can be substantially reduced. In the opinion of Valentin, Poesen and $\mathrm{Li}$ (2005), many techniques have proved to be effective for gully prevention and control, including vegetation cover, zero or reduced tillage, stone bunds, exclosures, terracing and check dams. They also opined that aboveground vegetation is known to favour water infiltration and to protect soil from erosion. They further claimed that gully erosion is reduced when soil physical properties such as structural stability and infiltrability is improved by the inherent strength of the tree root mat that binds the surface soils.

Izinyon, Ehiorobo and Adedeji (2013) asserted that stabilization of gullies involves the use of appropriate vegetative measures in the head, floor and sides of the gully. They further stated that once gullies begin to form, they must be treated as soon as possible, to minimize further damage and restore stability and that there are a multitude of physical and biological techniques which can be applied for effective gully treatment. In their opinion, the combination of the two measures (biophysical approach) is the best solution for effective gully control and for productive use of the gully area andthe construction of gully physical structures will be followed by the establishment of biological measures. They also reported that natural regeneration which comes after the gullies are protected and enclosed should also be considered in the overall rehabilitation scheme and attention must always be given to keeping the gully catchment well vegetated. According to 
Mwango, Msanya, Mtakwa, Kimaro, Deckers, Poesen, Massawe and Bethuel (2014), roots bind particles in the topsoil, which offer protection to soilthat is under pressure of detachment by sheet flow or concentrated flow. They claimed that the presenceof roots also increases the soil's roughness, thereby providing a greater capacity forinfiltration and for reducing surface runoff velocity. Ken and Wallie (2011) suggested that various artificial installations are useful in controlling gully erosion. They were also of the opinion that plants reduce soil erosion by intercepting raindrops, enhancing infiltration, transpiring soil water and by providing additional surface roughness by adding organic substances to the soil. They further stated that plant roots have a mechanical effect on soil strength and that by penetrating the soil mass, roots reinforce the soil and increase the soil shear strength. They also reported that an important aspect of rehabilitation work, which is most often neglected, is the follow-up maintenance of rehabilitation efforts and after installation, the erosion control structures need constant attention (particularly after rainfall) to ensure that they are still effective and that they will continue to contribute to improvement. Yang, MingHan and Shujuan (2013) asserted that increasing tree canopy coverage is not only beneficial in the control of gullies but also mitigates Urban Heat Island (UHI) effect and may reduce the incidence of heat-related diseases.

Table.1: Summary of Characteristics of some Studies that describe Landscape Design as a means to Control Gully Erosion

\begin{tabular}{|c|c|c|c|c|c|c|}
\hline $\mathbf{S} / \mathbf{N}$ & Author(s) & $\begin{array}{l}\text { Topic of } \\
\text { Research }\end{array}$ & Method(s) & Result(s) & Recommendations & Conclusion \\
\hline 1 & $\begin{array}{l}\text { Katherine, } \\
\text { Valerie, Carissa } \\
\text { and Eric (2002). }\end{array}$ & $\begin{array}{l}\text { A Property } \\
\text { Owners Guide } \\
\text { to Controlling } \\
\text { Erosion Using } \\
\text { Native } \\
\text { Vegetation for } \\
\text { Arrow Lakes. }\end{array}$ & $\begin{array}{l}\text { Literature } \\
\text { review of } \\
\text { materials, } \\
\text { physical } \\
\text { measurement, } \\
\text { observation. }\end{array}$ & $\begin{array}{l}\text { The use of live } \\
\text { branches is an effective } \\
\text { method for ensuring } \\
\text { water drains from a } \\
\text { slope without } \\
\text { removing parts of it. }\end{array}$ & $\begin{array}{l}\text { In order to stabilize } \\
\text { gullied slopes that } \\
\text { feed into rivers, } \\
\text { live branches } \\
\text { should be anchored } \\
\text { in a trench with a } \\
\text { stake and tied up. }\end{array}$ & $\begin{array}{l}\text { Eroded slopes } \\
\text { can generally be } \\
\text { stabilized using } \\
\text { vegetation and } \\
\text { bioengineering } \\
\text { methods. }\end{array}$ \\
\hline 2 & $\begin{array}{l}\text { Ken and Wallie } \\
(2011) .\end{array}$ & $\begin{array}{l}\text { Practical Soil } \\
\text { Erosion } \\
\text { Control and } \\
\text { Veld } \\
\text { Rehabilitation } \\
\text { in the Little } \\
\text { Karoo. }\end{array}$ & $\begin{array}{l}\text { Physical } \\
\text { measurement, } \\
\text { observation. }\end{array}$ & $\begin{array}{l}\text { Hollows facilitate } \\
\text { water infiltration on } \\
\text { bare capped soil } \\
\text { surfaces where very } \\
\text { little rain water } \\
\text { infiltrates the soil } \\
\text { surface. }\end{array}$ & $\begin{array}{l}\text { Existing rooted } \\
\text { vegetation should } \\
\text { not be disturbed in } \\
\text { any landscape as } \\
\text { this encourages the } \\
\text { occurrence of soil } \\
\text { degradation. }\end{array}$ & $\begin{array}{l}\text { Using a } \\
\text { combination of } \\
\text { methods } \\
\text { outlined will be } \\
\text { more effective } \\
\text { for rehabilitation } \\
\text { and also be more } \\
\text { cost-effective. }\end{array}$ \\
\hline 3 & $\begin{array}{l}\text { Yang, Ming-Han } \\
\text { and } \\
\text { Shujuan(2013). }\end{array}$ & $\begin{array}{l}\text { Design-with- } \\
\text { Nature for } \\
\text { Multifunctional } \\
\text { Landscapes: } \\
\text { Environmental } \\
\text { Benefits and } \\
\text { Social Barriers } \\
\text { in } \\
\text { Community } \\
\text { Development. }\end{array}$ & $\begin{array}{l}\text { Use of } \\
\text { Geographic } \\
\text { Information } \\
\text { System } \\
\text { (GIS), } \\
\text { literature } \\
\text { review of } \\
\text { materials. }\end{array}$ & $\begin{array}{l}\text { Design-With-Nature } \\
\text { concept demonstrates } \\
\text { benefits in reducing } \\
\text { runoff and Urban } \\
\text { Heat Island (UHI) } \\
\text { effect. }\end{array}$ & $\begin{array}{l}\text { Careful } \\
\text { considerations } \\
\text { must be paid to } \\
\text { human perceptions } \\
\text { and cultural values, } \\
\text { which shape or } \\
\text { reshape the way } \\
\text { landscape is } \\
\text { valued, } \\
\text { appreciated, and } \\
\text { managed. }\end{array}$ & $\begin{array}{l}\text { Design-With- } \\
\text { Nature approach } \\
\text { has } \\
\text { environmental } \\
\text { benefits on } \\
\text { storm water } \\
\text { management and } \\
\text { Urban Heat } \\
\text { Island (UHI) } \\
\text { effect. }\end{array}$ \\
\hline 4. & $\begin{array}{l}\text { Victor, Duran, } \\
\text { Carmen and } \\
\text { Rodriguez } \\
(2008) .\end{array}$ & $\begin{array}{l}\text { Soil-Erosion } \\
\text { and Runoff } \\
\text { Prevention by } \\
\text { Plant Covers: } \\
\text { A Review }\end{array}$ & $\begin{array}{l}\text { Literature } \\
\text { review of } \\
\text { materials. }\end{array}$ & $\begin{array}{l}\text { Results showed the } \\
\text { impacts of plant cover } \\
\text { on eroded } \\
\text { Mediterranean soil. }\end{array}$ & $\begin{array}{l}\text { Proven efficiency } \\
\text { of the plant covers } \\
\text { for the restoration } \\
\text { of degraded } \\
\text { environment } \\
\text { should be }\end{array}$ & $\begin{array}{l}\text { Careful } \\
\text { assessment of } \\
\text { soil for } \\
\text { sustainable } \\
\text { management } \\
\text { through the use }\end{array}$ \\
\hline
\end{tabular}




\begin{tabular}{|c|c|c|c|c|c|c|}
\hline & & & & & $\begin{array}{l}\text { considered more } \\
\text { widely. }\end{array}$ & $\begin{array}{l}\text { of plant covers } \\
\text { will aid the } \\
\text { avoidance of } \\
\text { catastrophic } \\
\text { degradation. }\end{array}$ \\
\hline 5. & McGarigal(2006). & $\begin{array}{l}\text { What is } \\
\text { Landscape }\end{array}$ & $\begin{array}{l}\text { Literature } \\
\text { review of } \\
\text { materials, use } \\
\text { of GIS. }\end{array}$ & $\begin{array}{l}\text { Basic approaches for } \\
\text { defining a landscape } \\
\text { and the importance of } \\
\text { landscape definition in } \\
\text { resource management } \\
\text { planning and analysis. }\end{array}$ & $\begin{array}{l}\text { A formal accuracy } \\
\text { assessment should } \\
\text { be completed that } \\
\text { involves an } \\
\text { extensive ground } \\
\text { truthing of the } \\
\text { maps representing } \\
\text { landscapes because } \\
\text { this will allow } \\
\text { precise estimates of } \\
\text { both errors of } \\
\text { omission and errors } \\
\text { of commission. }\end{array}$ & $\begin{array}{l}\text { The landscape } \\
\text { concept differs } \\
\text { from the } \\
\text { traditional } \\
\text { ecosystem } \\
\text { concept in } \\
\text { focusing on } \\
\text { groups of } \\
\text { ecosystems and } \\
\text { the interactions } \\
\text { among them. }\end{array}$ \\
\hline 6. & $\begin{array}{l}\text { Markus, Miloš, } \\
\text { Jozef, Štefan and } \\
\text { Pavol (2013). }\end{array}$ & $\begin{array}{l}\text { Human } \\
\text { Induced Soil } \\
\text { Erosion and } \\
\text { Gully System } \\
\text { Development } \\
\text { in the Late } \\
\text { Holocene and } \\
\text { Future } \\
\text { Perspectives on } \\
\text { Landscape } \\
\text { Evolution. }\end{array}$ & $\begin{array}{l}\text { Literature } \\
\text { review of } \\
\text { materials. }\end{array}$ & $\begin{array}{l}\text { Demonstration of the } \\
\text { interaction between } \\
\text { land use, soil erosion, } \\
\text { floodplain } \\
\text { development, and land } \\
\text { use changes of the } \\
\text { study area. }\end{array}$ & $\begin{array}{l}\text { Relative } \\
\text { significance of } \\
\text { slow processes and } \\
\text { resultant changes } \\
\text { on the complex } \\
\text { interconnections } \\
\text { between causes and } \\
\text { effects of land use } \\
\text { change and soil } \\
\text { erosion should be } \\
\text { observed and } \\
\text { understood. } \\
\text {. }\end{array}$ & $\begin{array}{l}\text { Today's } \\
\text { agricultural } \\
\text { potential and } \\
\text { possible future } \\
\text { land use } \\
\text { trajectories are } \\
\text { strongly } \\
\text { connected with } \\
\text { the legacies of } \\
\text { past land use } \\
\text { changes and soil } \\
\text { erosion. }\end{array}$ \\
\hline 7. & $\begin{array}{l}\text { Izinyon, } \\
\text { Ehiorobo and } \\
\text { Adedeji (2013). }\end{array}$ & $\begin{array}{l}\text { Appraisal of } \\
\text { Structural and } \\
\text { Non-Structural } \\
\text { Approaches to } \\
\text { Gully Erosion } \\
\text { Control. }\end{array}$ & $\begin{array}{l}\text { Literature } \\
\text { review of } \\
\text { materials, } \\
\text { rainfall } \\
\text { reading with } \\
\text { rain gauge. }\end{array}$ & $\begin{array}{l}\text { Results showed } \\
\text { limitations in the use of } \\
\text { structural approaches } \\
\text { to curb the advance of } \\
\text { gully erosion. }\end{array}$ & $\begin{array}{l}\text { The use of } \\
\text { biophysical } \\
\text { approach which is } \\
\text { a combination of } \\
\text { structural and non- } \\
\text { structural } \\
\text { approaches to } \\
\text { controlling gully } \\
\text { erosion should be } \\
\text { implemented. }\end{array}$ & $\begin{array}{l}\text { The study area is } \\
\text { susceptible to } \\
\text { gulling due to } \\
\text { high rainfall and } \\
\text { dispersive nature } \\
\text { of soil in the } \\
\text { study area hence } \\
\text { non-structural } \\
\text { methods should } \\
\text { be utilized to } \\
\text { control and } \\
\text { manage the } \\
\text { gully. }\end{array}$ \\
\hline 8. & $\begin{array}{l}\text { Valentin, Poesen } \\
\text { and Li (2005) }\end{array}$ & $\begin{array}{l}\text { Gully Erosion: } \\
\text { Impacts, } \\
\text { Factors and } \\
\text { Control. }\end{array}$ & $\begin{array}{l}\text { Literature } \\
\text { review of } \\
\text { materials. }\end{array}$ & $\begin{array}{l}\text { Although many } \\
\text { strategies to prevent } \\
\text { and combat gully } \\
\text { erosion have proved to } \\
\text { be effective, they are }\end{array}$ & $\begin{array}{l}\text { Research priorities } \\
\text { should include sub- } \\
\text { surface flow } \\
\text { erosion processes, } \\
\text { prediction models, }\end{array}$ & $\begin{array}{l}\text { Gully erosion is } \\
\text { not a process } \\
\text { limited to } \\
\text { badlands, } \\
\text { mountainous }\end{array}$ \\
\hline
\end{tabular}


rarely adopted by

farmers in the long run and at a large scale in the study area. and the causes of adoption or not of conservation strategies by farmers.

and hilly regions

but

a global and serious cause of land degradation affecting a wide variety of soils prone to crusting and/or piping.

\begin{tabular}{|c|c|c|c|c|c|c|}
\hline 9. & $\begin{array}{l}\text { Mwango, } \\
\text { Msanya, } \\
\text { Mtakwa, Kimaro, } \\
\text { Deckers, Poesen, } \\
\text { Massawe and } \\
\text { Bethuel (2014). }\end{array}$ & $\begin{array}{l}\text { Root Properties } \\
\text { of Plants Used } \\
\text { for Soil } \\
\text { Erosion } \\
\text { Control in the } \\
\text { Usambara } \\
\text { Mountains, } \\
\text { Tanzania. }\end{array}$ & $\begin{array}{l}\text { Physical } \\
\text { measurement, } \\
\text { observation, } \\
\text { literature } \\
\text { review of } \\
\text { materials. }\end{array}$ & $\begin{array}{l}\text { Results showed the } \\
\text { rooting characteristics } \\
\text { of Guatemala grass } \\
\text { (Tripsacumandersonii), } \\
\text { Napier grass } \\
\text { (Pennisetum } \\
\text { purpureum) and } \\
\text { Tithonia shrub } \\
\text { (Tithoniadiversifolia) } \\
\text { and their potential for } \\
\text { erosion control. }\end{array}$ & $\begin{array}{l}\text { In-depth studies to } \\
\text { investigate } \\
\text { physical Relative } \\
\text { Soil Detachment } \\
\text { (RSD) rate for } \\
\text { different soil } \\
\text { textures are } \\
\text { recommended in } \\
\text { order to come up } \\
\text { with more } \\
\text { representative RSD } \\
\text { models. }\end{array}$ & $\begin{array}{l}\text { Studies are } \\
\text { needed to } \\
\text { evaluate more } \\
\text { plants growing } \\
\text { in various } \\
\text { habitats for } \\
\text { selection of } \\
\text { plant species } \\
\text { that } \\
\text { can effectively } \\
\text { control } \\
\text { concentrated } \\
\text { flow erosion } \\
\text { rates. }\end{array}$ \\
\hline
\end{tabular}

Source: Researchers' design, 2018

\section{RESULTS AND DISCUSSION}

Landscape designis a highly effective means of controlling gully erosion. Table 1 summarizes the characteristics of some of the studies reviewed in this research. The topics of the studies summarized capture different approaches in landscape designfor controlling erosion and also made use of standard methods for carrying out research such as literature review, physical measurement, observation, Geographic Information System (GIS) and laboratory analysis. All the researchers (e.g., Katherine, Valerie, Carissa and Eric, 2002; Ken and Wallie, 2011; Victor, Duran, Carmen and Rodriguez,2008; Layne, Brien, Norton, Demisachew, Jaldesa ,Bedasa, and Dereje) have a unity of opinion on the use of plants or vegetation as an approach in landscape design for controlling gully erosionalthough some of them object to the use of structures or installationsonly ( e.g., Izinyon, Ehiorobo and Adedeji, 2013).

Previous authors made recommendations on different approaches to and concepts for landscape design for controllinggully erosion which include; (1) use of live branches to stabilize gullied slopes (Katherine, Valerie, Carissa and Eric 2002),(2) use of hollows which facilitate water infiltration (Ken and Wallie, 2011), (3) investigation of rooting characteristics of plants within the affected location (Mwango, Msanya, Mtakwa, Kimaro, Deckers, Poesen, Massawe and Bethuel, 2014), (4) design-withnature concept for landscape design (Yang, Ming-Han and Shujuan,2013); and (5) placement of sieve structures and 
other locally constructed structures for the control of gullies (Layne, Brien, Norton, Demisachew, Jaldesa , Bedasa , and Dereje, 2011).

\section{RECOMMENDATIONS}

The specific recommendations for the use of landscape design as a means for controlling gully erosion emanating from this paper are:

1. Introduction of vegetation in affected communities should not just be limited to planting of woody trees whose canopies intercept raindrops andform larger ones that have more kinetic energy to detach soil particles, but should include planting of grasses that would absorb the kinetic energy of the larger raindrops formed by the canopies.

2. Use of structures such as terraces which alter existing environmental conditions of the soil in any community should be discouraged. This is because, in the case of terraces, the ground is cemented causing absorptive capacity of the soil to be compromised hence, increasing runoff that detaches and transports soil particles.

3. The use of structures such as sieves which do not degrade the soil and can be easily accessed locally should be introduced to compliment vegetative control of gullies.

4. The practice of agroforestry which is a combination of planting of economictrees and cropping activities should be encouraged. This will encourage control of gullies and generation of income for the affected community.

5. Environmental legislations/regulations which discourage cementing of residences of individuals within gully erosion prone communities should be established and fines levied to offenders.

\section{CONCLUSION}

This paper discussed landscape design as a means of controlling gully erosion through a review of works done by previous authors. It reviewed two major aspects of landscape design: use of vegetation and the use of structures or installations in controlling gullies. The authors generally agreed that vegetation helps to curb gully erosion however; some of them were against the use of only structures in controlling gully erosion while others encouraged it. Landscape design is an effective tool in controlling gully erosion even though it may be subject to decay especially where the use of structures is concerned as illustrated by some of the authors' works reviewed.
This study therefore concludes that landscape design should be adopted to prevent and control gully erosion giving special attention to the use of vegetation as this not only helps to control gullies but also has other environmental benefits (e.g. improvement of aesthetic quality of the environment).

\section{ACKNOWLEDGEMENTS}

We appreciate the grace and empowerment of God Almighty who has been our source of strength from beginning to completion of this work. We also commend the effort of the relations, friends and well- wishers of the authors who contributed both financially and otherwise for making this review a success. Our gratitude extends to the Vice chancellor and the entire stakeholders of Chukwuemeka Odumegwu Ojukwu University, Uli, Anambra State, Nigeria for providing a platform for the study of Environmental Management. To all the lecturers, head of department and dean of the Environmental Sciences, we appreciate their collective efforts in making sure that the goal of environmental management is achieved in the institution. We are highly indebted to the chief author, Mr. Igwe, P.U. for his tireless effort towards an extensive research on the materials used for the review. We cannot fail to commend and appreciate the works of various authors used for the review. Finally, we thank the entire students of Environmental Management especially her final year students for their support throughout the review.

\section{REFERENCES}

[1] Abdulfatai, I. A., Okunlola, I. A., Akande, W. G., Momoh, L. O., and Ibrahim, K. O. (2014). Review of Gully Erosion in Nigeria: Causes, Impacts and Possible Solutions.Journal of Geosciences and Geomatics, 2(3):125-129.

[2] Amangabara, G.T. (2012). Analysis of Selected Failed Gully Erosion Control works in Imo State. Assessed at: www.researchgate.net, $2^{\text {nd }}$ November, 2017.

[3] Blair, W. (2014). Benefits of Landscape Design. Assessed at: www.element-outdoorliving.com, $2^{\text {nd }}$ November, 2017.

[4] Brevik, E.C, Cerdà, A., Mataix-Solera, J., Pereg, L., Quinton, J. N, Six, J., and Van, O.K. (2015). The Interdisciplinary Nature of Soil. Soil Journal, 1:117129.

[5] David, B. (2017). What is Landscape Design. Assessed at: www.thespruce.com, $2^{\text {nd }}$ November, 2017. 
[6] Ehiorobo, J. O., and Audu, H. A. P. (2012). Monitoring of Gully Erosion in an Urban Area using Geo-Information Technology. Journal of Emerging Trends in Engineering and Applied Sciences, 3(2):270275.

[7] Izinyon, O.C., Ehiorobo, J.O., and Adedeji, A.C. (2013). Appraisal of Structural and Non-Structural to Gully Erosion Control. A Case Study of Queen Ede Gully Site in Benin City. Assessed at: http://cayac.blogspot.com, $2^{\text {nd }}$ November, 2017.

[8] Katherine,E., Valerie,H., Carissa,C., and Eric,L. (2002). A property Owners Guide to Controlling Erosion Using Native Vegetation for Arrow Lakes. Assessed at: www.sgrc.selkirk.ca, $2^{\text {nd }}$ November, 2017.

[9] Ken, C., and Wallie, S. (2011). Practical Soil Erosion Control and Veld Rehabilitation in the Little Karoo. Assessed at:www.ostrichsa.co.za, $2^{\text {nd }}$ November, 2017.

[10] Khairulmaini, O.S., and Fatemeh,M. (2011). Gully Erosion in Semiarid Regions. Procedia Social and Behavioral Sciences, 19:651-661.

[11]Layne, D.C., Brien,E.N., Demisachew, T., Jaldesa, D., Bedasa,E., and Dereje, T. (2015). Sieve Structures to Control Gully Erosion on the Borana Plateau. Research Brief; Feed the Future-Adapting Livestock Systems to Climate Change, Colorado State University, Fort Collins, CO, USA. 5 p. Assessed at: http://digitalcommons.usu.edu/envs_facpub, $\quad 2^{\text {nd }}$ November, 2017.

[12]Lundy, L., and Wade, R. (2011). Integrating Sciences to Sustain Urban Ecosystem Services. Physical Geography,35:653-669.

Markus, S.D., Miloš, S., Jozef, M., Štefan, K., and Pavol, P. (2013). Human Induced Soil Erosion and Gully System Development in the Late Holocene and Future Perspectives on Landscape Evolution: The Myjava Hill Land. Geomorphology, 201:227-245.

[13] McGarigal, K. (2006). What is Landscape. Assessed at: www.umass.edu , $2^{\text {nd }}$ November, 2017.

[14] Morelli, J. (2010). Economic Sustainability and the Preservation of Environmental Management. Journal of Environmental Management, 14(8): 771-778.

[15] Mwango, S.B., Msanya, B.M., Mtakwa, P.W., Kimaro, D.N.,Deckers, J., Poesen,J., Massawe, V., and Bethuel, I. (2014). Root Properties of Plants Used for Soil Erosion Control in the Usambara Mountains, Tanzania. International Journal of Plant \& Soil Science, 3(12):1567-1580.
[16] Musa, D., Ahmed, A.I., Muhammed, U.B., and Abdul, H. (2016). Assessment of the Impacts of Gully Erosion on Auchi Settlement, Southern Nigeria.Journal of Geography and Regional Planning, 9(7):128-138.

[17] Musacchio, L.R. (2009). The Scientific Basis for the Design of Landscape Sustainability: A Framework for Translational Landscape Research and Practice for Designed Landscapes and the six Es of Landscape Sustainability. Landscape Ecology, 24: 993-100.

[18] Norton, J.B., Bowannie, J.F., Peynetsa, P., Quandelacy, W., and Siebert, S.F. (2002). Native American Methods for Conservation and Restoration of Semiarid Ephemeral Streams. Journal of Soil and Water Conservation, 57: 250-258.

[19] Nyssen, J., Poesen, J., Moeyersons, J., Deckers, J., Mitiku, H., and Lang, A. (2004). Human Impact on the Environment in the Ethiopian and Eritrean Highlands-A State of the Art. Earth Science Reviews, 64(3-4): 273-320.

[20] Poesen, J., and Valentin, C. (2003). Gully Erosion and Global Change. Catena, 50(2-4):87- 564.

[21] Poesen, J., Nachtergaele, J., Verstraeten, G., and Valentin, C. (2003). Gully Erosion and Environmental Change: Importance and Research Needs. Catena, 50(2-4):91-133.

[22] Poesen,J. (2011).Challenges in Gully Erosion Research. Landform Analysis, 17:5-9.

[23] Professional Landscape Design (2007). Erosion Control through Plants. Assessed at: www.lawnandlandscape.com, $2^{\text {nd }}$ November, 2017.

[24] Rickson, J. (2001). The Best is Yet to Come. Ground Engineering, 34(3):13-14.

[25] Valentin, C., Poesen, J., and Li, Y. (2005). Gully Erosion: Impacts, Factors and Control. Catena, 63:132-153

[26] VanDerZanden, A. M., and Rodie, S. N. (2008). Landscape Design; Theory and Application. Canada: Thomson Delmar Learning. Assessed at:www.elsevier.com, $2^{\text {nd }}$ November,2017.

[27] Víctor, H., Dur'an, Z., Carmen, R., and Rodr'iguez, P. (2008). Soil-erosion and runoff prevention by plant covers: A Review. Agronomy Sustainable Development, 28:65-82.

[28] Wasson, R.J., Caitcheon, G., Murray, A.S., McCulloch, M., and Quade, J. (2002). Sourcing Sediment Using Multiple Tracers in the Catchment of Lake Argyle, North-Western Australia. Environmental Management, 29(5):634-646. 
[29] Williams, J.D., and Tilt, K. (2006). Residential Landscape Design. Alabama Cooperative Extension System. Assessed at: $\underline{w w . a c e s . e d u}, 2^{\text {nd }}$ November, 2017.

[30] World Commission for Environment and Development (WCED) (1987). Our Common Future. Oxford University Press.

[31] Yang, B., Ming-Han, L., and Shujuan, L. (2013). Design-with-Nature for Multifunctional Landscapes: Environmental Benefits and Social Barriers in Community Development. Response to Plant Cover Strips on Semiarid Slopes. Land Degradation Development, 17:1-11.

[32] Yifan, D., Yongqiu, W., and Wen, W. (2011). The Comparison of the Effects of Two Approaches to Control Gully Erosion in the Black Soil Region of China. Landform Analysis, 17: 43-46.

[33]Zheng, B., Zhang, Y., and Chen, J. (2011). Preference to Home Landscape: Wildness or Neatness? Landscape and Urban Planning, 99: 1-8. 